\title{
Pulmonary Arterial Hypertension in Connective Tissue Diseases
}

\author{
Stephen C. Mathai and Paul M. Hassoun \\ Division of Pulmonary and Critical Care Medicine, Department of Medicine, Johns Hopkins \\ University, Baltimore, Maryland, USA
}

\section{Keywords}

connective tissue disease; pulmonary hypertension; scleroderma; systemic lupus erythematosus; mixed connective tissue disease; therapy

\section{Introduction}

Pulmonary arterial hypertension $(\mathrm{PAH})$ is a progressive disease caused by a remodeling of precapillary arterioles that leads to a progressive increase in pulmonary vascular resistance and right ventricular failure. PAH is associated with significant morbidity and mortality, despite the advent of specific therapies that target pathobiologic pathways implicated in the disease process [1-3]. PAH is can only be diagnosed by right heart catheterization (RHC) and is defined as a mean pulmonary artery pressure greater than $25 \mathrm{mmHg}$ in the absence of elevation of the pulmonary capillary wedge pressure. PAH includes a heterogeneous group of clinical entities sharing similar pathological changes that have been subcategorized as idiopathic PAH (IPAH), familial PAH, and pulmonary hypertension associated with other diseases such as connective tissue diseases (CTD), portopulmonary hypertension and pulmonary hypertension related to HIV infection, drugs and toxins. An updated classification of all pulmonary hypertension syndromes from the 4th World Symposium held at Dana Point, California in 2008, has been recently published [4].

The exact mechanisms involved in the pathogenesis of PAH remain vastly unknown but are likely to involve significant alterations in endothelial function [5], an understanding of which has led over the past two decades to targeted therapy for this disease [6]. Several lines of evidence also support a role for autoimmunity in the development of the pulmonary vascular changes, including the presence of circulating autoantibodies [7], pro-inflammatory cytokines (e.g., IL-1 and IL-6) [8], and association of PAH with auto-immune diseases and CTD such as systemic sclerosis (SSc), systemic lupus erythematosus (SLE), and mixed connective tissue disease (MCTD). Despite the similarities in disease pathogenesis and hemodynamic perturbations, outcomes in patients with CTD-associated PAH differ significantly from other forms of PAH. In particular, SSc-associated PAH (SSc-PAH)

(C) 2012 Elsevier Inc. All rights reserved.

Correspondance: Paul M. Hassoun, M.D., Professor of Medicine, Director, Pulmonary Hypertension Program, Johns Hopkins University, Division of Pulmonary and Critical Care Medicine, 1830 East Monument Street, Baltimore, MD 21205, Phone: 410614 5158, Fax: 443287 3349, phassoun@jhmi.edu.

Stephen C. Mathai, M.D. M.H.S., Assistant Professor of Medicine, Johns Hopkins University, Division of Pulmonary and Critical Care Medicine, 1830 East Monument Street, Baltimore, MD 21205, Phone: 410-614-6311, Fax: 410-614-7451, smathai4@jhmi.edu

The authors have nothing to disclose.

Publisher's Disclaimer: This is a PDF file of an unedited manuscript that has been accepted for publication. As a service to our customers we are providing this early version of the manuscript. The manuscript will undergo copyediting, typesetting, and review of the resulting proof before it is published in its final citable form. Please note that during the production process errors may be discovered which could affect the content, and all legal disclaimers that apply to the journal pertain. 
patients have a poorer response to therapy and significantly worse survival compared to IPAH patients [9-11]. While there are serologic and pathologic features suggestive of inflammation in both IPAH and SSc-PAH, inflammatory pathways and autoimmunity are likely more pronounced in SSc-PAH, perhaps explaining clinical discrepancies between the two syndromes $[9,10]$. Other connective tissue diseases such as SLE, MCTD, and to a lesser extent rheumatoid arthritis (RA), dermatomyositis, and Sjogren's syndrome can also be complicated by PAH and will be discussed separately in this review.

\section{Scleroderma}

SSc is a heterogeneous disorder characterized by dysfunction of the endothelium, dysregulation of fibroblasts resulting in excessive production of collagen, and abnormalities of the immune system [12]. Progressive fibrosis of the skin and internal organs is a pathologic hallmark of the disease resulting in major organ damage and failure explaining the high morbidity and early death. Genetic and environmental factors are thought to contribute to host susceptibility [13] in the context of autoimmune dysregulation. Whether presenting in the limited or diffuse form, SSc is a systemic disease with the propensity to involve multiple organ systems such as the gastrointestinal tract, the heart, kidneys and lungs [14]. Pulmonary manifestations include PAH, interstitial fibrosis, and increased susceptibility to lung neoplasms.

The use of a standard classification system for SSc has allowed more accurate estimates of incidence and prevalence of SSc, which vary according to geographic location [15], supporting a role for environmental factors in disease pathogenesis. Prevalence of SSc ranges from 30-70 cases per million in Europe and Japan [16-18] to 240 cases per million in the United States [15]. Incidence varies similarly by geographic area, with the highest rates found in the US ( 19 persons per million per year) [19].

\section{Scleroderma-associated PAH (SSc-PAH)}

The prevalence of PAH in SSc patients, when the diagnosis is based on right heart catheterization for assessment of filling pressures, is about 8-14\% [20,21]. Previous assessments based on echocardiographic measurements [22-25] have overestimated the true prevalence of SSc-PAH and should not be relied upon for establishing the diagnosis and initiating treatment. Echocardiography is limited in the diagnosis of PAH due to the inaccuracy of the Doppler signal in assessing true right ventricular systolic pressure [26] and the frequent inability to obtain an adequate Doppler signal, particularly in patients with CTD \{Murata, $1992 \# 251$ \}. Further, if estimated right ventricular pressure is indeed elevated, other diagnoses such as pulmonary venous hypertension cannot be excluded with certainty by echocardiography. However, while echocardiography overestimates the prevalence of $\mathrm{PAH}$ due to misclassification, it is likely that SSc-PAH remains overall under-diagnosed as suggested by the lower than expected prevalence of the disease in the few registries available [27-29].

\section{a. Pathophysiology}

There are early vascular changes in SSc [30] which include gaps between endothelial cells [31], cellular apoptosis [32], endothelial activation with expression of cell adhesion molecules, inflammatory cell recruitment, a procoagulant state [33], and remodeling of the small vessels with intimal proliferation and adventitial fibrosis leading to vessel obliteration. The extent of these vascular lesions in vital organs such as the lungs, kidneys and heart defines the prognosis of patients with SSc [34]. 
Specific endothelial injury is reflected by increased levels of soluble vascular cell adhesion molecule (sVCAM-1) [35], disturbances in angiogenesis reflected by increased levels of circulating vascular endothelial growth factor (VEGF) [36,37] and presence of angiostatic factors [36,38]. Increased VEGF may be a consequence of increased angiogenesis or profound disturbances in signaling in SSc. Dysregulated angiogenesis in SSc-PAH, exemplified by the up-regulation of VEGF a glycoprotein with potent angiogenic and vascular permeability-enhancing properties, is a predominant pathological feature of the disease and is a logical candidate for therapeutic targeting.

\section{b. Autoantibodies}

Several antibodies are frequently found in SSc-PAH such as antifibrillarin antibodies (antiU3-RNP) [39] and the poorly characterized anti-endothelial antibodies (aECA) which correlate with digital infarcts [40]. Antibodies to fibrin-bound tissue plasminogen activator in CREST patients [41] and in IPAH patients with HLA-DQ7 antigen [42], and antitopoisomerase II-alpha antibodies, particularly in association with HLA-B35 antigen [43], have been reported in SSc-PAH. aECA antibodies which can activate endothelial cells, induce the expression of adhesion molecules, and trigger apoptosis, are thought to play a role in the pathogenesis of PAH [44].

Fibroblasts are essential components of the pulmonary vascular wall remodeling in PAH and are found in the remodeled neointimal layer in both SSc-PAH and IPAH. In that regard, the detection of anti-fibroblast antibodies in the serum of SSc and IPAH patients [45,46] has significant pathogenic importance since these antibodies can activate fibroblasts and induce collagen synthesis, thus contributing potentially directly to the remodeling process.

Antibodies from sera of patients with SSc induce a pro-adhesive and pro-inflammatory response in normal fibroblasts [46]. Antifibroblast antibodies from sera of IPAH and SScPAH patients have distinct reactivity profiles [47] and react with fibroblast proteins involved in regulation of cytoskeletal function, cell contraction, cell and oxidative stress, cell energy metabolism and in different key cellular pathway [48].

Taken together, particularly in light of the positive response to immunosuppressive therapy for some patients with PAH associated with SLE and MCTD [49], these studies suggest that inflammation and autoimmunity play a major role in the pathogenesis of PAH, perhaps more specifically in CTD-associated PAH.

\section{c. Genetic factors}

Polymorphisms involving the bone morphogenetic protein receptor-2 (BMPRII) are present in over $80 \%$ of familial IPAH [50,51] and up to $25 \%$ of sporadic $[52,53]$ cases of IPAH. Additional candidate genes have been proposed to influence the pathogenesis of PAH [54]. Polymorphisms of the activin-receptor-like kinase $1(A L K I)$ gene, another member of the TGF $\beta$ receptor superfamily, have been reported in patients with hereditary hemorrhagic telangiecstasia (HHT) and PAH [55]. However, to date BMPR2 mutations have not been identified in two small cohorts of SSc-PAH patients [56,57].

Candidate genes associated with SSc have been reported in different populations and include a variant in the promoter of monocyte chemotactic protein-1 (MCP-1) [58]; two variants in CD19 (-499G $>$ T and a GT repeat polymorphism in the $3^{\prime}$-UTR region) [59]; a promoter and coding polymorphism in TNFA (TNFA-238A $>$ G, TNFA 489A $>$ G) [60]; a variant in the promoter of the IL-1 alpha gene (IL1A -889T) [61,62]; and a 3-SNP haplotype in IL10 [63]. A genome-wide association analysis provided evidence for association to multiple loci in a Native American population [64]. 
Recently, an association between an endoglin gene $(E N G)$ polymorphism and SSc-related PAH was identified. Wipf and colleagues demonstrated a significant lower frequency of the 6bINS allele in SSc-PAH patients as compared to controls or patients with SSc but no PAH [65]. Endoglin, a homodimeric membrane glycoprotein primarily present on human vascular endothelium, is part of the TGF- $\beta$ receptor complex. The functional significance of the $E N G$ polymorphism in SSc patients remains to be determined.

Thus, there is compelling data supporting a genetic basis for SSc. However, aside from the few examples cited above, the genes relevant to the pathogenesis and poor outcome associated with SSc-PAH have not been identified, and their definition will require robust, well-characterized large patient populations to provide adequate power for analysis.

\section{d. Clinical features}

Risk factors for the development of PAH in SSc patients include late-onset disease [66], an isolated reduction in DLCO, an FVC\%/DLCO\% ratio greater than $1.6[67,68]$, or a combined decreased DLCO/alveolar volume with elevation of serum $\mathrm{N}$-terminal pro-brain natriuretic peptide levels [69]\{Shah, \#642\}\{Negi, $1998 \# 164\}$, among others. (Table 1). Typically, patients with SSc-PAH are predominantly women, have limited sclerosis with predominantly anticentromere antibodies, are older and have seemingly less severe hemodynamic impairment compared to IPAH patients [10]. Clinical symptoms are non specific, including dyspnea, functional limitation which may be more severe than in IPAH due not only to older age but also to frequent involvement of the musculoskeletal system in these patients. SSc-PAH patients also tend to have other organ involvement such as renal dysfunction and intrinsic heart disease. Indeed patients with SSc (even in the absence of PAH) tend to have depressed RV function [70,71] as well as left ventricular systolic and diastolic dysfunction [72]. Like IPAH patients, SSc-PAH patients have severe RV dysfunction already at time of presentation but have more severely depressed RV contractility compared to IPAH patients [73]. In addition, SSc-PAH patients are more likely to have LV diastolic dysfunction and pericardial effusion (34\% compared to 13\% for IPAH) [10]. In both groups, pericardial effusion portends a particularly poor prognosis [10].

SSc-PAH patients also tend to have more severe hormonal and metabolic dysfunction such as high levels of N-terminal brain natriuretic peptide (N-TproBNP) [74] and hyponatremia [75]. Both N-TproBNP and hyponatremia have been shown, at baseline and with serial changes (for N-TproBNP [74]), to correlate with survival in PAH [74,75].

\section{e. Early Detection}

While IPAH is usually diagnosed late (patients presenting in WHO functional status III and IV), a population at risk for PAH such as SSc theoretically allows establishing measures for early detection. An algorithm for early detection of PAH may be helpful if based on a combination of symptoms and screening echocardiography (Figure 1) as exemplified by a recent large French registry where patients with SSc with tricuspid regurgitation velocity (TRV) jet by transthoracic echocardiography greater than $3 \mathrm{~m} / \mathrm{sec}$ or between 2.5 and $3 \mathrm{~m} /$ sec if accompanied by unexplained dyspnea, were systematically referred for right heart catheterization [20]. Investigators were able to detect incident cases of SSc-PAH with less severe disease (as judged on hemodynamic data) compared to patients with known disease. Therefore, unexplained dyspnea should prompt a search for PAH in these patients, in particular in the setting of a low single breath DLCO or declining DLCO over time [68], echocardiographic findings suggestive of the disease (elevated TRV jet or dilated RV or right atrium), or elevated levels of N-TproBNP which can reflect cardiac dysfunction and have been found to predict the presence of SSc-PAH [74]. Systematic screening should 
allow detection of early disease and prompt therapy which may theoretically be beneficial from a prognostic standpoint [76].

\section{f. Prognosis}

Patients with SSc-PAH have a worse prognosis compared to patients with other orms of PAH such as IPAH. Indeed, one-year survival rates for SSc-PAH patients range from 50$1 \%[9,11,21,25,77]$, considerably lower than the estimated $88 \%$ one year survival for IPAH patients [78]. Even when compared to patients with other forms of CTD-PAH, survival is markedly reduced in SSc-PAH. (Figure 2) In all patients with SSc, PAH significantly worsens survival and is one of the leading causes of mortality in these patients $[15,77,79]$.

\section{PAH associated with other connective tissue diseases}

PAH can complicate any connective tissue disease, most frequently SSc as discussed above, but also SLE, MCTD, RA, or other diseases such as Sjogren's syndrome and dermatomysositis.

\section{a. Systemic lupus erythematosus}

Pulmonary vascular involvement is common in SLE and, like in SSc, there is evidence of endothelial dysfunction with an imbalance between vasodilators and vasoconstrictors. Endothelin levels are high in patients with SLE, particularly in those patients with pulmonary hypertension. Other factors contributing to pulmonary vascular derangement in SLE include recurrent thromboembolic disease, particularly in patients with a hypercoaguable state from antiphospholipid antibodies which are present in up to $10 \%$ of patients with SLE [80], pulmonary vasculitis, and parenchymal disease (e.g., interstitial lung disease, and the shrinking lung syndrome from myositis of the diaphragm). Combined vasculitis and chronic hypoxia are frequent contributing offenders in these syndromes. Finally, pulmonary venous hypertension may be a consequence of left ventricular dysfunction, myocarditis, or Libman Sachs endocarditis.

The prevalence of PAH in SLE is unclear but is likely less than in SSc, affecting about 0.5$14 \%$ patients with SLE in a large review of the literature encompassing over 100 patients [81]. The patients are predominantly female (90\%), young (average age of 33 at time of diagnosis), and often suffer from Raynaud's phenomenon. The pathological lesions are often indistinguishable from IPAH or SSc-PAH lesions, with intimal hyperplasia, smooth muscle cell hypertrophy, and medial thickening. Survival, which was quite poor $(25-50 \%$ at 2 years) even compared to SSc-PAH in studies antedating specific PAH therapy, is now improved and estimated at 75\% [11]. It is also better than in SSc-PAH (Figure 2).

\section{b. Mixed connective tissue disease}

Patients with MCTD have clinical features which overlap between those of SSc, SLE, RA, and polymyositis. The exact prevalence of PAH in MCTD is unknown but is thought to be as high as 50\% [82]. PAH in these patients may occasionally respond to immunosuppressive drugs [49].

\section{c. Rheumatoid arthritis}

Both the prevalence and impact of PAH in patients with RA have not been well characterized but are thought to be relatively low compared to other CTD such as SSc, SLE and MCTD. 


\section{d. Primary Sjogren's syndrome}

Although primary Sjogren's syndrome (pSS) is a relatively common autoimmune disease with glandular and extraglandular manifestations, it is very rarely complicated by PAH. In a recent review by Launay et al of patients with pSS and PAH [83], the mean age at diagnosis of PAH of these almost exclusively female patients was 50 years. Patients had severe functional class (FC III and IV) and hemodynamic impairment. Standard therapy (with endothelin receptor antagonists, phosphodiesterase inhibitors or prostanoids) was typically ineffective despite an initial improvement. Some patients were reported to respond to immunosuppressive treatment. However, any conclusion regarding treatment is limited by the small size of this case report. Survival rate was low (66\% at 3 years).

\section{Therapy for PAH related to CTD}

While randomized, clinical trials of novel therapeutics for the treatment of PAH have included patients with PAH associated with CTD, the majority of these subjects included in trials were SSc-PAH. Given the differences in survival and potential differences in response to immunosuppressive therapy between the various forms of CTD associated PAH, the generalizability of the results of the clinical trials may be limited to only SSc-PAH.

However, the therapies discussed below are commonly used in all forms of CTD-associated $\mathrm{PAH}$, though the evidence base for diseases other than SSc is lacking.

Evidence of chronically impaired endothelial function [84-86], affecting vascular tone and remodeling, is the basis for current PAH therapy. Vasodilator therapy using high dose calcium channel blockers [87] is an effective long-term therapy for a minority of patients with IPAH who demonstrate acute and sustained vasodilation (e.g., to NO or adenosine) during hemodynamic testing [88]. However, since most patients with CTD-associated PAH patients fail to demonstrate a vasodilator response to acute testing [27], high dose calcium channel therapy is usually not indicated for these patients except at low dosage for Raynaud's syndrome. Further, because the proportion of CTD patients who demonstrate a positive vasodilator response is so low, current guidelines recommend vasodilator testing be performed on an individual basis in patients with CTD-associated PAH \{McLaughlin, 2009 $\# 733\}$.

\section{a. Anti-inflammatory drugs}

Inflammation may play a significant role in PAH associated with CTD. In that respect, it is interesting to note that occasional patients with severe PAH associated with some forms of CTD (such as SLE, primary Sjögren syndrome, and MCTD) have had dramatic improvement of their pulmonary vascular disease with corticosteroids and/or immunosuppressive therapy [49]. Unfortunately, this has not been the case for patients with SSc-PAH whose PAH is usually notoriously refractory to immunosuppressive drugs [49].

\section{b. Prostaglandins}

Prostacyclin (epoprostenol) has potent pulmonary vasodilator, anti-platelet aggregating and antiproliferative properties [89], and has proven effective in improving exercise capacity, cardiopulmonary hemodynamics, NYHA functional class, symptoms, as well as survival in patients with PAH when given by continuous infusion [90-92]. In SSc-PAH, continuous intravenous epoprostenol improves exercise capacity and hemodynamics [93], compared to conventional therapy, and may have long-term beneficial effects [94] although a clear effect on survival in these patients there has yet to be demonstrated.

Treprostinil, an analogue of epoprostenol suitable for continuous subcutaneous administration, has modest effects on symptoms and hemodynamics in PAH [95]. In a small 
study of 16 patients (among whom 6 had connective tissue disease related PAH), intravenous treprostinil improved hemodynamics 6 minute walk distance (6MWD), functional class (FC), and hemodynamics after 12 weeks of therapy [96]. Although the safety profile of this drug is similar to IV epoprostenol, required maintenance doses are usually twice as much as for epoprostenol. However, for patients with SSc-PAH and often severe and debilitating Raynaud's phenomenon, the lack of requirement of ice packing and less frequent mixing of the drug offer significant advantages.

Several reports of pulmonary edema in SSc-PAH patients treated with prostaglandin derivatives, both in acute and chronic settings, have raised the suspicion of increased prevalence of veno-occlusive disease in these patients [97,98], and concern about usefulness of these drugs for this entity. Nevertheless, intravenous prostaglandin therapy remains an option for patients with CTD-PAH with NYHA class IV. Considering the frequent digital problems and disabilities that these patients often experience, this form of therapy can be quite challenging and may increase the already heavy burden of disease in these patients. In summary, both epoprostenol and treprostinil are FDA approved for PAH, but are cumbersome therapies requiring continuous parenteral administration with the attendant numerous adverse effects (e.g., infection and possibility of pump failure [99]), which make these drugs less than ideal.

\section{c. Endothelin receptor antagonists}

In randomized, placebo-controlled trials bosentan therapy was shown to have a beneficial effect on functional class, 6-minute walk distance, time to clinical worsening and hemodynamics in PAH [100,101]. Roughly one fifth of these patients consisted of SSc-PAH patients while a large majority had a diagnosis of IPAH. In a subgroup analysis, there was a non-significant trend towards a positive treatment effect on 6MWD among the SSc-PAH patients treated with bosentan compared to placebo [101]. At most, bosentan therapy prevented deterioration in these patients. Reasons for the less than optimal effect of therapy in patients with SSc-PAH are unknown but may be related to the severity of PAH at time of presentation, as well as other factors such as potentially more severe RV and pulmonary vascular dysfunction compared to patients with other forms of PAH (e.g., IPAH).

In a recent analysis of patients with CTD-PAH (e.g., patients with lupus, overlap syndrome, and other rheumatologic disorders) included in randomized clinical trials of bosentan, there was a trend toward improvement in $6 \mathrm{MWD}$ and improved survival compared to historical cohorts [102]. Single center experience suggests that long-tem outcome of first-line bosentan monotherapy is inferior in SSc-PAH compared to IPAH patients, with no change in FC and worse survival in the former group [103]. Since ET-1 appears to play an important pathogenic role in the development of SSc-PAH, contributing to vascular damage and fibrosis, inhibiting ET-1 remains a rational therapeutic strategy in these patients. As an example of mechanistic effect, in a small study of 35 patients with SSc (10 of whom had SSc-PAH), bosentan treatment appeared to reduce endothelial cell (as determined by endothelial soluble serum factors such as ICAM-1, VCAM-1, P-selection and PECAM-1) and $\mathrm{T}$ cell subset (assessed by expression of lymphocyte function-associated antigen-1, very late antigen-4, and L-selectin on CD3 Tcells) activation [104]. Aside from improving pulmonary hypertension, ET-1 receptor antagonists (specifically bosentan) cause significant reductions in the occurrence of new digital ulcerations; however, preexisting ulcers do not seem to improve with this therapy [105].

In an effort to target the vasoconstrictive effects of endothelin while preserving its vasodilatory action, selective endothelin-A receptor antagonists have been developed. Sitaxsentan, which had been approved in Europe for treatment of PAH, demonstrated exercise capacity, quality of life and hemodynamics in a post-hoc analysis of a RCT that 
included 42 patients with CTD-PAH \{Girgis, 2007 \#584\}. However, recently, this drug was removed from the market due to significant hepatotoxicity and death. A large placebocontrolled, randomized trial of ambrisentan, the only currently FDA-approved selective endothelin receptor antagonist, improved 6MWD in PAH patients at week 12 of treatment, however, the effect was larger in patients with IPAH compared to patients with CTD-PAH (range of 50-60 meters versus 15-23 meters, respectively)[106]. Ambrisentan is generally well tolerated although peripheral edema (in up to $20 \%$ of patients [106]) and congestive heart failure have been reported.

\section{d. Phosphodiesterase inhibitors}

Sildenafil, a phosphodiesterase type $\mathrm{V}$ inhibitor that reduces the catabolism of cGMP, thereby enhancing the cellular effects mediated by nitric oxide, has become a widely used and highly efficacious therapy for PAH. The pivotal SUPER trial demonstrated that sildenafil therapy improved 6 MWD in patients with IPAH, CTD-PAH, or PA associated with repaired congenital heart disease (patients were predominantly FC II or III) at all three doses tested (20, 40, and $80 \mathrm{mg}$, given three times a day) [107]. The current FDArecommended dose is $20 \mathrm{mgs}$ three times a day since there were no significant differences in clinical effects and time to clinical worsening at week 12 between all doses tested. In a posthoc subgroup analysis of 84 patients with PAH related to CTD (forty-five percent of whom had SSc-PAH), data from the SUPER study suggest that sildenafil at a dose of $20 \mathrm{mgs}$ improved exercise capacity (6 MWD), hemodynamic measures and functional class after 12 weeks of therapy [108]. However, there was no effect for the dose of $80 \mathrm{mgs}$ three times a day on hemodynamics in this subgroup of patients with CTD-related PAH [108]. For this reason and because of the potential of increased side-effects (such as bleeding from arteriovenous malformations) at high doses, a sildenafil dosage of $20 \mathrm{mgs}$ three times a day is recommended for SSc-PAH patients (and patients with PAH associated with other forms of CTD) as standard therapy. Higher doses are occasionally attempted in case of limited response. The impact of long-term sildenafil therapy on survival in these patients remains to be determined. Finally, tadalafil, another phosphodiesterase inhibitor, has now been shown to be effective for PAH [109] although subgroup analysis has not been performed yet and thus its effects on CTD-PAH remain unclear. Tadalafil has the advantage over sildenafil of single daily dosage.

\section{e. Combination therapy}

It is now common practice to add drugs when patients fail to improve on monotherapy. Adding inhaled iloprost to patients receiving bosentan has been shown to be beneficial in a small, randomized trial. Combining inhaled iloprost with sildenafil is mechanistically appealing and anecdotally efficacious $[110,111]$ as these drugs target separate, potentially synergistic pathways. Several multicenter trials are now exploring the efficacy of various combinations of two oral drugs or one oral and one inhaled drug. The recently published results of the PACES trial demonstrate that adding sildenafil (at a dose of $80 \mathrm{mgs}$ three times a day) to intravenous epoprostenol improves exercise capacity, hemodynamic measurements, time to clinical worsening, and quality of life [112]. About $21 \%$ of these patients had CTD, including 11\% with SSc-PAH. Although no specific subgroup analysis is provided, improvement was apparently mainly in patients with IPAH. In a smaller one center clinical trial, adding sildenafil to patients with IPAH or scleroderma-related PAH after they failed initial monotherapy with bosentan, demonstrates that combination therapy improved the 6MWD and FC in IPAH patients. The outcome in patients with SSc-PAH was less favorable, although combination therapy may have halted clinical deterioration. In addition, there were more side-effects reported in the SSc-PAH compared to the IPAH patients, including hepatotoxicity that developed after addition of sildenafil to bosentan monotherapy [113]. 


\section{f. Anticoagulation}

Based essentially on retrospective data showing a survival advantage [87,114], anticoagulation is routinely recommended in the treatment of IPAH patients. However, the role of anticoagulation in other forms of PAH, in particular in CTD-PAH is much less clear. Theoretically, there is potential for increased bleeding in patients with CTD, particularly with SSc where intestinal telangiectasias may be common. In our experience, less than $50 \%$ of SSc-PAH patients started on anticoagulation remain on therapy long-term because of bleeding complications (e.g., often related to occult bleeding in the gastrointestinal tract) which are often difficult to diagnose.

\section{g. Tyrosine kinase inhibitors}

The finding that there is pathologically aberrant proliferation of endothelial and smooth muscle cells in PAH, as well increased expression of secreted growth factors such as VEGF and bFGF, has caused a shift in paradigm in treatment strategies for this disease as some investigators have likened this condition to a neoplastic process reminiscent of advanced solid tumors [115]. As a result, anti-neoplastic drugs have been tested in experimental models $[116,117]$. The results of a phase II multicenter trial to evaluate the safety, tolerability, and efficacy of this drug in patients with PAH have recently published and indicate that imatinib is well tolerated in PAH patients. While there was no significant change in 6 minute walk distance (primary end-point) there was a significant decrease in pulmonary vascular resistance and an increase in cardiac output in imatinib-treated patients versus placebo[118]. Whether these new anti-neoplastic drugs with anti-tyrosine kinase activity will have a role in SSc (where there is evidence for both dysregulated proliferation and increased expression of growth factors such as VEGF[119]) or in IPAH remains to be determined. Interestingly, a single case report suggests significant improvement of right ventricular function with imatinib treatment in a SSc-PAH patient. Also of note is that imatinib is being investigated for SSc-related interstitial lung disease[120].

\section{h. Lung transplantation}

Lung transplantation (LT) is typically offered as a last resort to patients with PAH who fail medical therapy. CTD is not an absolute contraindication to LT; however, patients with CTD-PAH frequently suffer from associated morbidity and organ dysfunction other than the lung, which places them at a significantly increased risk for LT. Motility disorder of the esophagus and gastroesophageal reflux in patients with SSc significantly enhance the postoperative potential of aspiration and damage to the recipient lung. For these reasons, patients with SSc-PAH are often denied LT consideration. However, if properly screened and approved for LT, patients with SSc experience similar rates of survival 2 years after the procedure compared with patients who receive LT for pulmonary fibrosis or IPAH [121]. In addition, a recent retrospective study suggests that the 1-year survival rate is similar for SSc patients (transplanted for respiratory failure related to PAH or interstitial lung disease) compared to patients with IPF although acute rejection appears to be more common for the former group [122].

\section{Conclusion}

In summary, pulmonary hypertension is a common complication of CTD, particularly SSc where it carries a very poor prognosis. Despite modern therapy for PAH, survival of patients with CTD-PAH remains unacceptably low. Possible reasons include an increased prevalence of pulmonary veno-occlusive lung disease in SSc-PAH patients [123], or more severe vascular lesions affecting not only proximal and distal pulmonary vessels but also the heart (such as inflammatory myocarditis) in CTD. Thus, a better understanding of the underlying pathophysiology affecting the heart and pulmonary vessels in CTD is needed for better 
targeted therapy. Whether specific anti-inflammatory agents or drugs targeting tyrosine kinase activity will have any role in CTD-PAH is unclear at this time but needs to be explored.

\section{Acknowledgments}

Supported by: NHLBI K23 HL092287 (SCM) and P50 HL084946 (PMH)

\section{References}

1. D’Alonzo GE, Barst RJ, Ayres SM, Bergofsky EH, Brundage BH, Detre KM, Fishman AP, Goldring RM, Groves BM, Kernis JT, et al. Survival in patients with primary pulmonary hypertension. Results from a national prospective registry. Ann Intern Med. 1991; 115:343-349. [PubMed: 1863023]

2. Gaine SP, Rubin LJ. Primary pulmonary hypertension. Lancet. 1998; 352:719-725. [PubMed: 9729004]

3. Rich S, Dantzker DR, Ayres SM, Bergofsky EH, Brundage BH, Detre KM, Fishman AP, Goldring RM, Groves BM, Koerner SK, et al. Primary pulmonary hypertension. A national prospective study. Ann Intern Med. 1987; 107:216-223. [PubMed: 3605900]

4. Simonneau G, Robbins IM, Beghetti M, Channick RN, Delcroix M, Denton CP, Elliott CG, Gaine SP, Gladwin MT, Jing ZC, Krowka MJ, Langleben D, Nakanishi N, Souza R. Updated clinical classification of pulmonary hypertension. J Am Coll Cardiol. 2009; 54:S43-54. [PubMed: 19555858]

5. Budhiraja R, Tuder RM, Hassoun PM. Endothelial dysfunction in pulmonary hypertension. Circulation. 2004; 109:159-165. [PubMed: 14734504]

6. Humbert M, Sitbon O, Simonneau G. Treatment of pulmonary arterial hypertension. N Engl J Med. 2004; 351:1425-1436. [PubMed: 15459304]

7. Isern RA, Yaneva M, Weiner E, Parke A, Rothfield N, Dantzker D, Rich S, Arnett FC. Autoantibodies in patients with primary pulmonary hypertension: association with anti-Ku. Am J Med. 1992; 93:307-312. [PubMed: 1524083]

8. Humbert M, Monti G, Brenot F, Sitbon O, Portier A, Grangeot-Keros L, Duroux P, Galanaud P, Simonneau G, Emilie D. Increased interleukin-1 and interleukin-6 serum concentrations in severe primary pulmonary hypertension. Am J Respir Crit Care Med. 1995; 151:1628-1631. [PubMed: 7735624]

9. Kawut SM, Taichman DB, Archer-Chicko CL, Palevsky HI, Kimmel SE. Hemodynamics and survival in patients with pulmonary arterial hypertension related to systemic sclerosis. Chest. 2003; 123:344-350. [PubMed: 12576350]

10. Fisher MR, Mathai SC, Champion HC, Girgis RE, Housten-Harris T, Hummers L, Krishnan JA, Wigley F, Hassoun PM. Clinical differences between idiopathic and scleroderma-related pulmonary hypertension. Arthritis Rheum. 2006; 54:3043-3050. [PubMed: 16947776]

11. Condliffe R, Kiely DG, Peacock AJ, Corris PA, Gibbs JS, Vrapi F, Das C, Elliot CA, Johnson M, DeSoyza J, Torpy C, Goldsmith K, Hodgkins D, Hughes RJ, Pepke-Zaba J, Coghlan JG. Connective tissue disease-associated pulmonary arterial hypertension in the modern treatment era. Am J Respir Crit Care Med. 2009; 179:151-157. [PubMed: 18931333]

12. Jimenez SA, Derk CT. Following the molecular pathways toward an understanding of the pathogenesis of systemic sclerosis. Ann Intern Med. 2004; 140:37-50. [PubMed: 14706971]

13. Tan FK. Systemic sclerosis: the susceptible host (genetics and environment). Rheum Dis Clin North Am. 2003; 29:211-237. [PubMed: 12841292]

14. LeRoy EC, Black C, Fleischmajer R, Jablonska S, Krieg T, Medsger TA Jr, Rowell N, Wollheim F. Scleroderma (systemic sclerosis): classification, subsets and pathogenesis. J Rheumatol. 1988; 15:202-205. [PubMed: 3361530]

15. Mayes MD. Scleroderma epidemiology. Rheum Dis Clin North Am. 2003; 29:239-254. [PubMed: 12841293]

Heart Fail Clin. Author manuscript; available in PMC 2013 July 01. 
16. Silman A, Jannini S, Symmons D, Bacon P. An epidemiological study of scleroderma in the West Midlands. Br J Rheumatol. 1988; 27:286-290. [PubMed: 3261609]

17. Tamaki T, Mori S, Takehara K. Epidemiological study of patients with systemic sclerosis in Tokyo. Arch Dermatol Res. 1991; 283:366-371. [PubMed: 1796818]

18. Allcock RJ, Forrest I, Corris PA, Crook PR, Griffiths ID. A study of the prevalence of systemic sclerosis in northeast England. Rheumatology (Oxford). 2004; 43:596-602. [PubMed: 14872101]

19. Mayes MD, Lacey JV Jr, Beebe-Dimmer J, Gillespie BW, Cooper B, Laing TJ, Schottenfeld D. Prevalence, incidence, survival, and disease characteristics of systemic sclerosis in a large US population. Arthritis Rheum. 2003; 48:2246-2255. [PubMed: 12905479]

20. Hachulla E, Gressin V, Guillevin L, Carpentier P, Diot E, Sibilia J, Kahan A, Cabane J, Frances C, Launay D, Mouthon L, Allanore Y, Tiev KP, Clerson P, de Groote P, Humbert M. Early detection of pulmonary arterial hypertension in systemic sclerosis: a French nationwide prospective multicenter study. Arthritis Rheum. 2005; 52:3792-3800. [PubMed: 16320330]

21. Mukerjee D, St George D, Coleiro B, Knight C, Denton CP, Davar J, Black CM, Coghlan JG. Prevalence and outcome in systemic sclerosis associated pulmonary arterial hypertension: application of a registry approach. Ann Rheum Dis. 2003; 62:1088-1093. [PubMed: 14583573]

22. Battle RW, Davitt MA, Cooper SM, Buckley LM, Leib ES, Beglin PA, Tischler MD. Prevalence of pulmonary hypertension in limited and diffuse scleroderma. Chest. 1996; 110:1515-1519. [PubMed: 8989070]

23. Stupi AM, Steen VD, Owens GR, Barnes EL, Rodnan GP, Medsger TA Jr. Pulmonary hypertension in the CREST syndrome variant of systemic sclerosis. Arthritis Rheum. 1986; 29:515-524. [PubMed: 3707629]

24. Sacks DG, Okano Y, Steen VD, Curtiss E, Shapiro LS, Medsger TA Jr. Isolated pulmonary hypertension in systemic sclerosis with diffuse cutaneous involvement: association with serum anti-U3RNP antibody. J Rheumatol. 1996; 23:639-642. [PubMed: 8730118]

25. MacGregor AJ, Canavan R, Knight C, Denton CP, Davar J, Coghlan J, Black CM. Pulmonary hypertension in systemic sclerosis: risk factors for progression and consequences for survival. Rheumatology (Oxford). 2001; 40:453-459. [PubMed: 11312386]

26. Fisher MR, Forfia PR, Chamera E, Housten-Harris T, Champion HC, Girgis RE, Corretti MC, Hassoun PM. Accuracy of Doppler echocardiography in the hemodynamic assessment of pulmonary hypertension. Am J Respir Crit Care Med. 2009; 179:615-621. [PubMed: 19164700]

27. Humbert M, Sitbon O, Chaouat A, Bertocchi M, Habib G, Gressin V, Yaici A, Weitzenblum E, Cordier JF, Chabot F, Dromer C, Pison C, Reynaud-Gaubert M, Haloun A, Laurent M, Hachulla E, Simonneau G. Pulmonary arterial hypertension in France: results from a national registry. Am $\mathbf{J}$ Respir Crit Care Med. 2006; 173:1023-1030. [PubMed: 16456139]

28. Peacock AJ, Murphy NF, McMurray JJ, Caballero L, Stewart S. An epidemiological study of pulmonary arterial hypertension. Eur Respir J. 2007; 30:104-109. [PubMed: 17360728]

29. Badesch DB, Raskob GE, Elliott CG, Krichman AM, Farber HW, Frost AE, Barst RJ, Benza RL, Liou TG, Turner M, Giles S, Feldkircher K, Miller DP, McGoon MD. Pulmonary arterial hypertension: baseline characteristics from the REVEAL Registry. Chest. 137:376-387. [PubMed: 19837821]

30. LeRoy EC. Systemic sclerosis. A vascular perspective. Rheum Dis Clin North Am. 1996; 22:675694. [PubMed: 8923590]

31. Fleischmajer R, Perlish JS. Capillary alterations in scleroderma. J Am Acad Dermatol. 1980; 2:161-170. [PubMed: 7364973]

32. Sgonc R, Gruschwitz MS, Boeck G, Sepp N, Gruber J, Wick G. Endothelial cell apoptosis in systemic sclerosis is induced by antibody-dependent cell-mediated cytotoxicity via CD95. Arthritis Rheum. 2000; 43:2550-2562. [PubMed: 11083280]

33. Cerinic MM, Valentini G, Sorano GG, D’Angelo S, Cuomo G, Fenu L, Generini S, Cinotti S, Morfini M, Pignone A, Guiducci S, Del Rosso A, Kalfin R, Das D, Marongiu F. Blood coagulation, fibrinolysis, and markers of endothelial dysfunction in systemic sclerosis. Semin Arthritis Rheum. 2003; 32:285-295. [PubMed: 12701039]

34. Altman RD, Medsger TA Jr, Bloch DA, Michel BA. Predictors of survival in systemic sclerosis (scleroderma). Arthritis Rheum. 1991; 34:403-413. [PubMed: 1901491] 
35. Denton CP, Bickerstaff MC, Shiwen X, Carulli MT, Haskard DO, Dubois RM, Black CM. Serial circulating adhesion molecule levels reflect disease severity in systemic sclerosis. Br J Rheumatol. 1995; 34:1048-1054. [PubMed: 8542206]

36. Distler O, Del Rosso A, Giacomelli R, Cipriani P, Conforti ML, Guiducci S, Gay RE, Michel BA, Bruhlmann P, Muller-Ladner U, Gay S, Matucci-Cerinic M. Angiogenic and angiostatic factors in systemic sclerosis: increased levels of vascular endothelial growth factor are a feature of the earliest disease stages and are associated with the absence of fingertip ulcers. Arthritis Res. 2002; 4:R11. [PubMed: 12453314]

37. Choi JJ, Min DJ, Cho ML, Min SY, Kim SJ, Lee SS, Park KS, Seo YI, Kim WU, Park SH, Cho CS. Elevated vascular endothelial growth factor in systemic sclerosis. J Rheumatol. 2003; 30:1529-1533. [PubMed: 12858453]

38. Hebbar M, Peyrat JP, Hornez L, Hatron PY, Hachulla E, Devulder B. Increased concentrations of the circulating angiogenesis inhibitor endostatin in patients with systemic sclerosis. Arthritis Rheum. 2000; 43:889-893. [PubMed: 10765935]

39. Okano Y, Steen VD, Medsger TA Jr. Autoantibody to U3 nucleolar ribonucleoprotein (fibrillarin) in patients with systemic sclerosis. Arthritis Rheum. 1992; 35:95-100. [PubMed: 1731817]

40. Negi VS, Tripathy NK, Misra R, Nityanand S. Antiendothelial cell antibodies in scleroderma correlate with severe digital ischemia and pulmonary arterial hypertension. J Rheumatol. 1998; 25:462-466. [PubMed: 9517764]

41. Fritzler MJ, Hart DA, Wilson D, Garcia-De La Torre I, Salazar-Paramo M, Vazquez-Del Mercado M, Senecal JL, Loyau S, Angles-Cano E. Antibodies to fibrin bound tissue type plasminogen activator in systemic sclerosis. J Rheumatol. 1995; 22:1688-1693. [PubMed: 8523346]

42. Morse JH, Barst RJ, Fotino M, Zhang Y, Flaster E, Gharavi AE, Fritzler MJ, Dominguez M, Angles-Cano E. Primary pulmonary hypertension, tissue plasminogen activator antibodies, and HLA-DQ7. Am J Respir Crit Care Med. 1997; 155:274-278. [PubMed: 9001324]

43. Grigolo B, Mazzetti I, Meliconi R, Bazzi S, Scorza R, Candela M, Gabrielli A, Facchini A. Antitopoisomerase II alpha autoantibodies in systemic sclerosis-association with pulmonary hypertension and HLA-B35. Clin Exp Immunol. 2000; 121:539-543. [PubMed: 10971522]

44. Nicolls MR, Taraseviciene-Stewart L, Rai PR, Badesch DB, Voelkel NF. Autoimmunity and pulmonary hypertension: a perspective. Eur Respir J. 2005; 26:1110-1118. [PubMed: 16319344]

45. Tamby MC, Chanseaud Y, Humbert M, Fermanian J, Guilpain P, Garcia-de-la-Pena-Lefebvre P, Brunet S, Servettaz A, Weill B, Simonneau G, Guillevin L, Boissier MC, Mouthon L. Antiendothelial cell antibodies in idiopathic and systemic sclerosis associated pulmonary arterial hypertension. Thorax. 2005; 60:765-772. [PubMed: 16135682]

46. Chizzolini C, Raschi E, Rezzonico R, Testoni C, Mallone R, Gabrielli A, Facchini A, Del Papa N, Borghi MO, Dayer JM, Meroni PL. Autoantibodies to fibroblasts induce a proadhesive and proinflammatory fibroblast phenotype in patients with systemic sclerosis. Arthritis Rheum. 2002; 46:1602-1613. [PubMed: 12115192]

47. Tamby MC, Humbert M, Guilpain P, Servettaz A, Dupin N, Christner JJ, Simonneau G, Fermanian J, Weill B, Guillevin L, Mouthon L. Antibodies to fibroblasts in idiopathic and sclerodermaassociated pulmonary hypertension. Eur Respir J. 2006; 28:799-807. [PubMed: 16774952]

48. Terrier B, Tamby MC, Camoin L, Guilpain P, Broussard C, Bussone G, Yaici A, Hotellier F, Simonneau G, Guillevin L, Humbert M, Mouthon L. Identification of target antigens of antifibroblast antibodies in pulmonary arterial hypertension. Am J Respir Crit Care Med. 2008; 177:1128-1134. [PubMed: 18276943]

49. Sanchez O, Sitbon O, Jais X, Simonneau G, Humbert M. Immunosuppressive therapy in connective tissue diseases-associated pulmonary arterial hypertension. Chest. 2006; 130:182-189. [PubMed: 16840400]

50. Deng Z, Morse JH, Slager SL, Cuervo N, Moore KJ, Venetos G, Kalachikov S, Cayanis E, Fischer SG, Barst RJ, Hodge SE, Knowles JA. Familial primary pulmonary hypertension (gene PPH1) is caused by mutations in the bone morphogenetic protein receptor-II gene. Am J Hum Genet. 2000; 67:737-744. [PubMed: 10903931]

51. Lane KB, Machado RD, Pauciulo MW, Thomson JR, Phillips JA 3rd, Loyd JE, Nichols WC, Trembath RC. Heterozygous germline mutations in BMPR2, encoding a TGF-beta receptor, cause 
familial primary pulmonary hypertension. The International PPH Consortium. Nat Genet. 2000; 26:81-84. [PubMed: 10973254]

52. Newman JH, Trembath RC, Morse JA, Grunig E, Loyd JE, Adnot S, Coccolo F, Ventura C, Phillips JA 3rd, Knowles JA, Janssen B, Eickelberg O, Eddahibi S, Herve P, Nichols WC, Elliott G. Genetic basis of pulmonary arterial hypertension: current understanding and future directions. $\mathrm{J}$ Am Coll Cardiol. 2004; 43:33S-39S. [PubMed: 15194176]

53. Koehler R, Grunig E, Pauciulo MW, Hoeper MM, Olschewski H, Wilkens H, Halank M, Winkler J, Ewert R, Bremer H, Kreuscher S, Janssen B, Nichols WC. Low frequency of BMPR2 mutations in a German cohort of patients with sporadic idiopathic pulmonary arterial hypertension. J Med Genet. 2004; 41:e127. [PubMed: 15591269]

54. Morse JH, Deng Z, Knowles JA. Genetic aspects of pulmonary arterial hypertension. Ann Med. 2001; 33:596-603. [PubMed: 11817654]

55. Trembath RC, Thomson JR, Machado RD, Morgan NV, Atkinson C, Winship I, Simonneau G, Galie N, Loyd JE, Humbert M, Nichols WC, Morrell NW, Berg J, Manes A, McGaughran J, Pauciulo M, Wheeler L. Clinical and molecular genetic features of pulmonary hypertension in patients with hereditary hemorrhagic telangiectasia. N Engl J Med. 2001; 345:325-334. [PubMed: 11484689]

56. Morse J, Barst R, Horn E, Cuervo N, Deng Z, Knowles J. Pulmonary hypertension in scleroderma spectrum of disease: lack of bone morphogenetic protein receptor 2 mutations. J Rheumatol. 2002; 29:2379-2381. [PubMed: 12415595]

57. Tew MB, Arnett FC, Reveille JD, Tan FK. Mutations of bone morphogenetic protein receptor type II are not found in patients with pulmonary hypertension and underlying connective tissue diseases. Arthritis Rheum. 2002; 46:2829-2830. [PubMed: 12384956]

58. Karrer S, Bosserhoff AK, Weiderer P, Distler O, Landthaler M, Szeimies RM, Muller-Ladner U, Scholmerich J, Hellerbrand C. The -2518 promotor polymorphism in the MCP-1 gene is associated with systemic sclerosis. Journal of Investigative Dermatology. 2005; 124(1):92-98. [PubMed: 15654958]

59. Tsuchiya N, Kuroki K, Fujimoto M, Murakami Y, Tedder TF, Tokunaga K, Takehara K, Sato S. Association of a functional CD19 polymorphism with susceptibility to systemic sclerosis. Arthritis Rheum. 2004; 50:4002-4007. [PubMed: 15593213]

60. Tolusso B, Fabris M, Caporali R, Cuomo G, Isola M, Soldano F, Montecucco C, Valentini G, Ferraccioli G. -238 and +489 TNF-alpha along with TNF-RII gene polymorphisms associate with the diffuse phenotype in patients with Systemic Sclerosis. Immunol Lett. 2005; 96:103-108. [PubMed: 15585313]

61. Kawaguchi Y, Tochimoto A, Ichikawa N, Harigai M, Hara M, Kotake S, Kitamura Y, Kamatani N. Association of IL1A gene polymorphisms with susceptibility to and severity of systemic sclerosis in the Japanese population. Arthritis Rheum. 2003; 48:186-192. [PubMed: 12528118]

62. Hutyrova B, Lukac J, Bosak V, Buc M, du Bois R, Petrek M. Interleukin 1alpha single-nucleotide polymorphism associated with systemic sclerosis. J Rheumatol. 2004; 31:81-84. [PubMed: 14705223]

63. Crilly A, Hamilton J, Clark CJ, Jardine A, Madhok R. Analysis of the 5 ' flanking region of the interleukin 10 gene in patients with systemic sclerosis. Rheumatology (Oxford). 2003; 42:12951298. [PubMed: 12867583]

64. Zhou X, Tan FK, Wang N, Xiong M, Maghidman S, Reveille JD, Milewicz DM, Chakraborty R, Arnett FC. Genome-wide association study for regions of systemic sclerosis susceptibility in a Choctaw Indian population with high disease prevalence. Arthritis Rheum. 2003; 48:2585-2592. [PubMed: 13130478]

65. Wipff J, Kahan A, Hachulla E, Sibilia J, Cabane J, Meyer O, Mouthon L, Guillevin L, Junien C, Boileau C, Allanore Y. Association between an endoglin gene polymorphism and systemic sclerosis-related pulmonary arterial hypertension. Rheumatology (Oxford). 2007; 46:622-625. [PubMed: 17166870]

66. Schachna L, Wigley FM, Chang B, White B, Wise RA, Gelber AC. Age and risk of pulmonary arterial hypertension in scleroderma. Chest. 2003; 124:2098-2104. [PubMed: 14665486] 
67. Chang B, Schachna L, White B, Wigley FM, Wise RA. Natural history of mild-moderate pulmonary hypertension and the risk factors for severe pulmonary hypertension in scleroderma. $\mathbf{J}$ Rheumatol. 2006; 33:269-274. [PubMed: 16465657]

68. Steen V, Medsger TA Jr. Predictors of isolated pulmonary hypertension in patients with systemic sclerosis and limited cutaneous involvement. Arthritis Rheum. 2003; 48:516-522. [PubMed: 12571862]

69. Allanore Y, Borderie D, Avouac J, Zerkak D, Meune C, Hachulla E, Mouthon L, Guillevin L, Meyer O, Ekindjian OG, Weber S, Kahan A. High N-terminal pro-brain natriuretic peptide levels and low diffusing capacity for carbon monoxide as independent predictors of the occurrence of precapillary pulmonary arterial hypertension in patients with systemic sclerosis. Arthritis Rheum. 2008; 58:284-291. [PubMed: 18163505]

70. Hsiao SH, Lee CY, Chang SM, Lin SK, Liu CP. Right heart function in scleroderma: insights from myocardial Doppler tissue imaging. J Am Soc Echocardiogr. 2006; 19:507-514. [PubMed: 16644433]

71. Lee CY, Chang SM, Hsiao SH, Tseng JC, Lin SK, Liu CP. Right heart function and scleroderma: insights from tricuspid annular plane systolic excursion. Echocardiography. 2007; 24:118-125. [PubMed: 17313542]

72. Meune C, Avouac J, Wahbi K, Cabanes L, Wipff J, Mouthon L, Guillevin L, Kahan A, Allanore Y. Cardiac involvement in systemic sclerosis assessed by tissue-doppler echocardiography during routine care: A controlled study of 100 consecutive patients. Arthritis Rheum. 2008; 58:18031809. [PubMed: 18512815]

73. Overbeek MJ, Lankhaar JW, Westerhof N, Voskuyl AE, Boonstra A, Bronzwaer JG, Marques KM, Smit EF, Dijkmans BA, Vonk-Noordegraaf A. Right ventricular contractility in systemic sclerosisassociated and idiopathic pulmonary arterial hypertension. Eur Respir J. 2008; 31:1160-1166. [PubMed: 18216049]

74. Williams MH, Handler CE, Akram R, Smith CJ, Das C, Smee J, Nair D, Denton CP, Black CM, Coghlan JG. Role of N-terminal brain natriuretic peptide (N-TproBNP) in scleroderma-associated pulmonary arterial hypertension. Eur Heart J. 2006; 27:1485-1494. [PubMed: 16682379]

75. Forfia PR, Mathai SC, Fisher MR, Housten-Harris T, Hemnes AR, Champion HC, Girgis RE, Hassoun PM. Hyponatremia predicts right heart failure and poor survival in pulmonary arterial hypertension. Am J Respir Crit Care Med. 2008; 177:1364-1369. [PubMed: 18356560]

76. Williams MH, Das C, Handler CE, Akram MR, Davar J, Denton CP, Smith CJ, Black CM, Coghlan JG. Systemic sclerosis associated pulmonary hypertension: improved survival in the current era. Heart. 2006; 92:926-932. [PubMed: 16339813]

77. Koh ET, Lee P, Gladman DD, Abu-Shakra M. Pulmonary hypertension in systemic sclerosis: an analysis of 17 patients. Br J Rheumatol. 1996; 35:989-993. [PubMed: 8883438]

78. McLaughlin VV, Shillington A, Rich S. Survival in primary pulmonary hypertension: the impact of epoprostenol therapy. Circulation. 2002; 106:1477-1482. [PubMed: 12234951]

79. Steen VD, Medsger TA. Changes in causes of death in systemic sclerosis, 1972-2002. Ann Rheum Dis. 2007; 66:940-944. [PubMed: 17329309]

80. Pope J. An update in pulmonary hypertension in systemic lupus erythematosus - do we need to know about it? Lupus. 2008; 17:274-277. [PubMed: 18413406]

81. Haas C. Pulmonary hypertension associated with systemic lupus erythematosus. Bull Acad Natl Med. 2004; 188:985-997. discussion 997. [PubMed: 15651427]

82. Sullivan WD, Hurst DJ, Harmon CE, Esther JH, Agia GA, Maltby JD, Lillard SB, Held CN, Wolfe $\mathrm{JF}$, Sunderrajan EV, et al. A prospective evaluation emphasizing pulmonary involvement in patients with mixed connective tissue disease. Medicine (Baltimore). 1984; 63:92-107. [PubMed: 6700436]

83. Launay D, Hachulla E, Hatron PY, Jais X, Simonneau G, Humbert M. Pulmonary arterial hypertension: a rare complication of primary Sjogren syndrome: report of 9 new cases and review of the literature. Medicine (Baltimore). 2007; 86:299-315. [PubMed: 17873760]

84. Giaid A, Saleh D. Reduced expression of endothelial nitric oxide synthase in the lungs of patients with pulmonary hypertension. N Engl J Med. 1995; 333:214-221. [PubMed: 7540722] 
85. Tuder RM, Cool CD, Geraci MW, Wang J, Abman SH, Wright L, Badesch D, Voelkel NF. Prostacyclin synthase expression is decreased in lungs from patients with severe pulmonary hypertension. Am J Respir Crit Care Med. 1999; 159:1925-1932. [PubMed: 10351941]

86. Giaid A, Yanagisawa M, Langleben D, Michel RP, Levy R, Shennib H, Kimura S, Masaki T, Duguid WP, Stewart DJ. Expression of endothelin-1 in the lungs of patients with pulmonary hypertension. N Engl J Med. 1993; 328:1732-1739. [PubMed: 8497283]

87. Rich S, Kaufmann E, Levy PS. The effect of high doses of calcium-channel blockers on survival in primary pulmonary hypertension. N Engl J Med. 1992; 327:76-81. [PubMed: 1603139]

88. Sitbon O, Humbert M, Jais X, Ioos V, Hamid AM, Provencher S, Garcia G, Parent F, Herve P, Simonneau G. Long-term response to calcium channel blockers in idiopathic pulmonary arterial hypertension. Circulation. 2005; 111:3105-3111. [PubMed: 15939821]

89. Vane JR, Anggard EE, Botting RM. Regulatory functions of the vascular endothelium. N Engl J Med. 1990; 323:27-36. [PubMed: 2113184]

90. Barst RJ, Rubin LJ, Long WA, McGoon MD, Rich S, Badesch DB, Groves BM, Tapson VF, Bourge RC, Brundage BH, et al. A comparison of continuous intravenous epoprostenol (prostacyclin) with conventional therapy for primary pulmonary hypertension. The Primary Pulmonary Hypertension Study Group. N Engl J Med. 1996; 334:296-302. [PubMed: 8532025]

91. McLaughlin VV, Genthner DE, Panella MM, Rich S. Reduction in pulmonary vascular resistance with long-term epoprostenol (prostacyclin) therapy in primary pulmonary hypertension. N Engl J Med. 1998; 338:273-277. [PubMed: 9445406]

92. Rubin LJ, Mendoza J, Hood M, McGoon M, Barst R, Williams WB, Diehl JH, Crow J, Long W. Treatment of primary pulmonary hypertension with continuous intravenous prostacyclin (epoprostenol). Results of a randomized trial. Ann Intern Med. 1990; 112:485-491. [PubMed: 2107780]

93. Badesch DB, Tapson VF, McGoon MD, Brundage BH, Rubin LJ, Wigley FM, Rich S, Barst RJ, Barrett PS, Kral KM, Jobsis MM, Loyd JE, Murali S, Frost A, Girgis R, Bourge RC, Ralph DD, Elliott CG, Hill NS, Langleben D, Schilz RJ, McLaughlin VV, Robbins IM, Groves BM, Shapiro $\mathrm{S}$, Medsger TA Jr. Continuous intravenous epoprostenol for pulmonary hypertension due to the scleroderma spectrum of disease. A randomized, controlled trial. Ann Intern Med. 2000; 132:425434. [PubMed: 10733441]

94. Badesch DB, McGoon MD, Barst RJ, Tapson VF, Rubin LJ, Wigley FM, Kral KM, Raphiou IH, Crater GD. Longterm survival among patients with scleroderma-associated pulmonary arterial hypertension treated with intravenous epoprostenol. J Rheumatol. 2009; 36:2244-2249. [PubMed: 19723905]

95. Simonneau G, Barst RJ, Galie N, Naeije R, Rich S, Bourge RC, Keogh A, Oudiz R, Frost A, Blackburn SD, Crow JW, Rubin LJ. Continuous subcutaneous infusion of treprostinil, a prostacyclin analogue, in patients with pulmonary arterial hypertension: a double-blind, randomized, placebo-controlled trial. Am J Respir Crit Care Med. 2002; 165:800-804. [PubMed: 11897647]

96. Tapson VF, Gomberg-Maitland M, McLaughlin VV, Benza RL, Widlitz AC, Krichman A, Barst RJ. Safety and efficacy of IV treprostinil for pulmonary arterial hypertension: a prospective, multicenter, open-label, 12-week trial. Chest. 2006; 129:683-688. [PubMed: 16537868]

97. Farber HW, Graven KK, Kokolski G, Korn JH. Pulmonary edema during acute infusion of epoprostenol in a patient with pulmonary hypertension and limited scleroderma. J Rheumatol. 1999; 26:1195-1196. [PubMed: 10332990]

98. Palmer SM, Robinson LJ, Wang A, Gossage JR, Bashore T, Tapson VF. Massive pulmonary edema and death after prostacyclin infusion in a patient with pulmonary veno-occlusive disease. Chest. 1998; 113:237-240. [PubMed: 9440597]

99. Galie N, Manes A, Branzi A. Emerging medical therapies for pulmonary arterial hypertension. Prog Cardiovasc Dis. 2002; 45:213-224. [PubMed: 12525997]

100. Channick RN, Simonneau G, Sitbon O, Robbins IM, Frost A, Tapson VF, Badesch DB, Roux S, Rainisio M, Bodin F, Rubin LJ. Effects of the dual endothelin-receptor antagonist bosentan in patients with pulmonary hypertension: a randomised placebo-controlled study. Lancet. 2001; 358:1119-1123. [PubMed: 11597664] 
101. Rubin LJ, Badesch DB, Barst RJ, Galie N, Black CM, Keogh A, Pulido T, Frost A, Roux S, Leconte I, Landzberg M, Simonneau G. Bosentan therapy for pulmonary arterial hypertension. N Engl J Med. 2002; 346:896-903. [PubMed: 11907289]

102. Denton CP, Humbert M, Rubin L, Black CM. Bosentan treatment for pulmonary arterial hypertension related to connective tissue disease: a subgroup analysis of the pivotal clinical trials and their open-label extensions. Ann Rheum Dis. 2006; 65:1336-1340. [PubMed: 16793845]

103. Girgis RE, Mathai SC, Krishnan JA, Wigley FM, Hassoun PM. Long-term outcome of bosentan treatment in idiopathic pulmonary arterial hypertension and pulmonary arterial hypertension associated with the scleroderma spectrum of diseases. J Heart Lung Transplant. 2005; 24:16261631. [PubMed: 16210140]

104. Iannone F, Riccardi MT, Guiducci S, Bizzoca R, Cinelli M, Matucci-Cerinic M, Lapadula G. Bosentan regulates the expression of adhesion molecules on circulating $\mathrm{T}$ cells and serum soluble adhesion molecules in systemic sclerosis-associated pulmonary arterial hypertension. Ann Rheum Dis. 2008; 67:1121-1126. [PubMed: 18029384]

105. Jain M, Varga J. Bosentan for the treatment of systemic sclerosis-associated pulmonary arterial hypertension, pulmonary fibrosis and digital ulcers. Expert Opin Pharmacother. 2006; 7:14871501. [PubMed: 16859432]

106. Galie N, Olschewski H, Oudiz RJ, Torres F, Frost A, Ghofrani HA, Badesch DB, McGoon MD, McLaughlin VV, Roecker EB, Gerber MJ, Dufton C, Wiens BL, Rubin LJ. Ambrisentan for the treatment of pulmonary arterial hypertension: results of the ambrisentan in pulmonary arterial hypertension, randomized, double-blind, placebo-controlled, multicenter, efficacy (ARIES) study 1 and 2. Circulation. 2008; 117:3010-3019. [PubMed: 18506008]

107. Galie N, Ghofrani HA, Torbicki A, Barst RJ, Rubin LJ, Badesch D, Fleming T, Parpia T, Burgess G, Branzi A, Grimminger F, Kurzyna M, Simonneau G. Sildenafil citrate therapy for pulmonary arterial hypertension. N Engl J Med. 2005; 353:2148-2157. [PubMed: 16291984]

108. Badesch DB, Hill NS, Burgess G, Rubin LJ, Barst RJ, Galie N, Simonneau G. Sildenafil for pulmonary arterial hypertension associated with connective tissue disease. J Rheumatol. 2007; 34:2417-2422. [PubMed: 17985403]

109. Galie N, Brundage BH, Ghofrani HA, Oudiz RJ, Simonneau G, Safdar Z, Shapiro S, White RJ, Chan M, Beardsworth A, Frumkin L, Barst RJ. Tadalafil therapy for pulmonary arterial hypertension. Circulation. 2009; 119:2894-2903. [PubMed: 19470885]

110. McLaughlin VV, Oudiz RJ, Frost A, Tapson VF, Murali S, Channick RN, Badesch DB, Barst RJ, Hsu HH, Rubin LJ. Randomized study of adding inhaled iloprost to existing bosentan in pulmonary arterial hypertension. Am J Respir Crit Care Med. 2006; 174:1257-1263. [PubMed: 16946127]

111. Hoeper MM, Faulenbach C, Golpon H, Winkler J, Welte T, Niedermeyer J. Combination therapy with bosentan and sildenafil in idiopathic pulmonary arterial hypertension. Eur Respir J. 2004; 24:1007-1010. [PubMed: 15572546]

112. Simonneau G, Rubin LJ, Galie N, Barst RJ, Fleming TR, Frost AE, Engel PJ, Kramer MR, Burgess G, Collings L, Cossons N, Sitbon O, Badesch DB. Addition of sildenafil to long-term intravenous epoprostenol therapy in patients with pulmonary arterial hypertension: a randomized trial. Ann Intern Med. 2008; 149:521-530. [PubMed: 18936500]

113. Mathai SC, Girgis RE, Fisher MR, Champion HC, Housten-Harris T, Zaiman A, Hassoun PM. Addition of sildenafil to bosentan monotherapy in pulmonary arterial hypertension. Eur Respir J. 2007; 29:469-475. [PubMed: 17079256]

114. Fuster V, Steele PM, Edwards WD, Gersh BJ, McGoon MD, Frye RL. Primary pulmonary hypertension: natural history and the importance of thrombosis. Circulation. 1984; 70:580-587. [PubMed: 6148159]

115. Adnot S. Lessons learned from cancer may help in the treatment of pulmonary hypertension. J Clin Invest. 2005; 115:1461-1463. [PubMed: 15931382]

116. Schermuly RT, Dony E, Ghofrani HA, Pullamsetti S, Savai R, Roth M, Sydykov A, Lai YJ, Weissmann N, Seeger W, Grimminger F. Reversal of experimental pulmonary hypertension by PDGF inhibition. J Clin Invest. 2005; 115:2811-2821. [PubMed: 16200212] 
117. Moreno-Vinasco L, Gomberg-Maitland M, Maitland ML, Desai AA, Singleton PA, Sammani S, Sam L, Liu Y, Husain AN, Lang RM, Ratain MJ, Lussier YA, Garcia JG. Genomic assessment of a multikinase inhibitor, sorafenib, in a rodent model of pulmonary hypertension. Physiol Genomics. 2008; 33:278-291. [PubMed: 18303084]

118. Ghofrani HA, Morrell NW, Hoeper MM, Olschewski H, Peacock AJ, Barst RJ, Shapiro S, Golpon H, Toshner M, Grimminger F, Pascoe S. Imatinib in Pulmonary Arterial Hypertension Patients with Inadequate Response to Established Therapy. Am J Respir Crit Care Med.

119. Grigoryev DN, Mathai SC, Fisher MR, Girgis RE, Zaiman AL, Housten-Harris T, Cheadle C, Gao L, Hummers LK, Champion HC, Garcia JG, Wigley FM, Tuder RM, Barnes KC, Hassoun PM. Identification of candidate genes in scleroderma-related pulmonary arterial hypertension. Transl Res. 2008; 151:197-207. [PubMed: 18355767]

120. ten Freyhaus H, Dumitrescu D, Bovenschulte H, Erdmann E, Rosenkranz S. Significant improvement of right ventricular function by imatinib mesylate in scleroderma-associated pulmonary arterial hypertension. Clin Res Cardiol. 2009; 98:265-267. [PubMed: 19219392]

121. Schachna L, Medsger TA Jr, Dauber JH, Wigley FM, Braunstein NA, White B, Steen VD, Conte JV, Yang SC, McCurry KR, Borja MC, Plaskon DE, Orens JB, Gelber AC. Lung transplantation in scleroderma compared with idiopathic pulmonary fibrosis and idiopathic pulmonary arterial hypertension. Arthritis Rheum. 2006; 54:3954-3961. [PubMed: 17133609]

122. Saggar R, Khanna D, Furst DE, Belperio JA, Park GS, Weigt SS, Kubak B, Ardehali A, Derhovanessian A, Clements PJ, Shapiro S, Hunter C, Gregson A, Fishbein MC, Lynch JP 3rd, Ross DJ, Saggar R. Systemic sclerosis and bilateral lung transplantation: a single center experience. Eur Respir J.

123. Dorfmuller P, Humbert M, Perros F, Sanchez O, Simonneau G, Muller KM, Capron F. Fibrous remodeling of the pulmonary venous system in pulmonary arterial hypertension associated with connective tissue diseases. Hum Pathol. 2007; 38:893-902. [PubMed: 17376507] 


\section{Synopsis}

Pulmonary arterial hypertension (PAH) may complicate diverse connective tissue diseases (CTD) such as systemic sclerosis (SSc), systemic lupus erythematosus (SLE), mixed connective tissue disease (MCTD), and rheumatoid arthritis (RA), among others. Approximately $10 \%$ of patients with SSc will develop PAH; the prevalence is much lower in the other CTD. However, PAH is an important contributor to morbidity and mortality in all forms of CTD. Despite similarities in clinical presentation, hemodynamic perturbations, and pathogenesis, patients with CTD associated PAH (CTD-PAH) usually have a poorer response to $\mathrm{PAH}$-specific medications and a poorer prognosis than patients with idiopathic PAH (IPAH). Similarly, while select patients with CTD-PAH may be candidates for lung transplantation, the results are less favorable than for IPAH due to comorbidities and complications specifically associated with CTD. Future research focusing on the specific vascular and cardiac abnormalities in CTD-PAH is imperative to develop novel, targeted treatment. 
1. Pulmonary arterial hypertension (PAH) is a common complication of connective tissue diseases (CTD) particularly scleroderma

2. When complicating CTD PAH significantly worsens survival and is a leading cause of death in these patients

3. Scleroderma-associated PAH carries a significantly worse prognosis compared to other forms of PAH such as idiopathic PAH (IPAH)

4. Standard PAH-specific therapy is not as effective in CTD-associated PAH compared to IPAH

5. There is a need for a better understanding of underlying mechanisms of CTDassociated PAH in order to design targeted therapy. 


\section{Routine testing:}

Clinical evaluation

Yearly echocardiogram

Yearly PFTs

$\mathrm{N}-T$ proBNP serum level

Clinical Suspicion based on:

- Unexplained dyspnea

- Physical findings suggestive of right heart disease: $\uparrow P 2$; pedal edema

- $\downarrow$ DLCO or DLCO/alveolar volume

- FVC\%/DLCO $\%>1.6$

- $\uparrow \mathrm{N}$-TproBNP

No evidence of $\mathrm{PH}$

$\mathrm{RV}$ size/function normal<smiles>[13CH2][13CH3]</smiles>

Seek other causes of dyspnea (e.g., ILD)

Perform HRCT

Continue observation

\section{Transthoracic Echocardiogram}
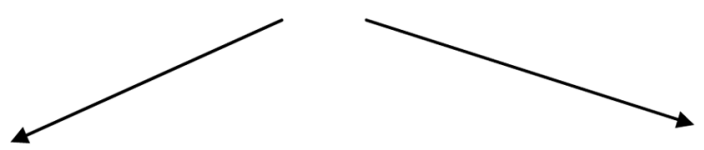

TRV jet $>2.5 \mathrm{~m} / \mathrm{sec}$ with unexplained dyspnea or TRV jet $>3 \mathrm{~m} / \mathrm{sec}$

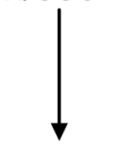

\section{Perform RHC}

Figure 1. Algorithm for Detection of PAH in Patients with Systemic Sclerosis Algorithm showing routine clinical tests in patients with systemic sclerosis aimed at early detection of pulmonary arterial hypertension or other causes of cardiac dysfunction (e.g., left ventricular dysfunction)

Abbreviations: PFTs-Pulmonary function tests; DLCO-single breath diffusing capacity to carbon monoxide; FVC-forced vital capacity; RV-right ventricle; TRV-tricuspid regurgitation jet; RHC-right heart catheterization. 


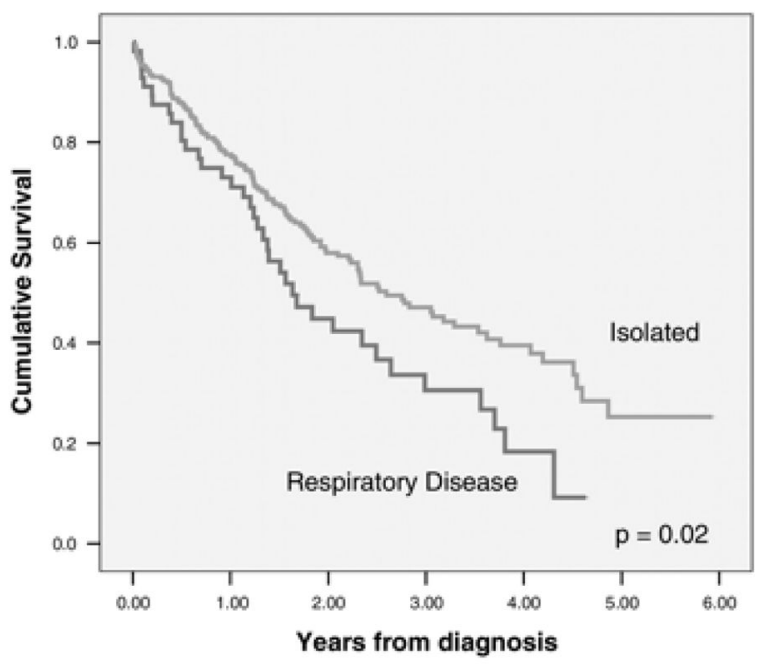

Patients at risk

$\begin{array}{lllllll}259 & 179 & 94 & 53 & 27 & 6 & \text { Isolated } \\ 56 & 38 & 18 & 10 & 3 & & \text { Respiratory disease }\end{array}$

Figure 2. Survival in SSc-PAH compared to SLE-PAH

Survival from diagnosis for patients with PAH associated with SSc compared to PAH associated with SLE. From Condliffe R et al. Am J Resp Crit Care Med 2009 (permission pending) 
Table 1

Clinical Risk Factors for the Development of PAH in Systemic Sclerosis

\begin{tabular}{|l|}
\hline Limited SSc \\
\hline Late age of onset of SSc \\
\hline Raynaud's Phenomenon \\
\hline Number of Telangectasias \\
\hline Decreased DL $_{\mathrm{CO}}$ \\
\hline FVC \%: $\mathrm{DL}_{\mathrm{CO}} \%>1.6$ \\
\hline Increased NT-proBNP \\
\hline Antibodies (e.g. anti-U3 RNP) \\
\hline
\end{tabular}

